九州大学学術情報リポジトリ

Kyushu University Institutional Repository

\title{
Effect of Hydrostatic Pressure on the Inactivation of Salmonel la and Campylobacter Species at Low Temperature
}

\section{Igura, Noriyuki}

Laboratory of Food Process Engineering, Division of Food Biotechnology, Department of Bioscience and Biotechnology, Faculty of Agriculture, Kyushu University

Hiro, Norihiko

Laboratory of Food Process Engineering, Division of Food Biotechnology, Department of Bioscience and Biotechnology, Graduate School of Bioresource and Bioenvironmental Sciences, Kyushu University

Shimoda, Mitsuya

Laboratory of Food Process Engineering, Division of Food Biotechnology, Department of Bioscience and Biotechnology, Faculty of Agriculture, Kyushu University

Hayakawa, Isao

Laboratory of Food Process Engineering, Division of Food Biotechnology, Department of Bioscience and Biotechnology, Faculty of Agriculture, Kyushu University

https://doi.org/10.5109/4534

出版情報 : 九州大学大学院農学研究院紀要. 48 (1/2), pp.121-126, 2003-10-01. Faculty of Agriculture, Kyushu University

バージョン :

権利関係 : 


\title{
Effect of Hydrostatic Pressure on the Inactivation of Salmonella and Campylobacter Species at Low Temperature
}

\author{
Noriyuki IGURA ${ }^{\dagger}$, Norihiko HIRO*, Mitsuya SHIMODA, \\ and Isao HAYAKAWA \\ Laboratory of Food Process Engineering, Division of Food Biotechnology, \\ Department of Bioscience and Biotechnology, Faculty of Agriculture, \\ Kyushu University, Fukuoka 812-8581, Japan \\ (Received June 24, 2003 and accepted July 15, 2003)
}

\begin{abstract}
Salmonella typhimurium cells were treated with high hydrostatic pressure $(<200 \mathrm{MPa})$ at 0,5 and $10^{\circ} \mathrm{C}$ in $0.9 \% \mathrm{NaCl}$ solution. Inactivation efficiency by high hydrostatic pressure treatment increased with decrease in the treatment temperature. Two Campylobacter species were also treated with high hydrostatic pressure at $0{ }^{\circ} \mathrm{C}$ in $0.9 \% \mathrm{NaCl}$ solution and poultry thighs. Both Campylobacter species were effectively inactivated in $0.9 \% \mathrm{NaCl}$ solution compared to poultry thighs. The appearance of poultry thighs slightly discolored by the high hydrostatic pressure treatment at $200 \mathrm{MPa}, 0^{\circ} \mathrm{C}$ for $60 \mathrm{~min}$.
\end{abstract}

\section{INTRODUCTION}

High hydrostatic pressure has recently been exploited as a new method for sterilizing and processing food (Shigehisa et al. 1991, Cheftel 1995, Yuste et al. 2001). Pressure induces several irreversible changes in food ingredients and concomitants depending on the magnitude of the pressure, as observed with heat. For example, protein including enzymes are denatured and inactivated (Bridgman 1914, Hayakawa et al. 1992, 1996), microorganisms are killed (Sale et al. 1970, Hayakawa et al. 1994). Shigehisa et al. (1991) reported that some gram-negative microorganisms could be inactivated by high hydrostatic pressure at $>3000 \mathrm{~atm}$ (ca. $300 \mathrm{MPa}$ ) for $10 \mathrm{~min}$ at $25^{\circ} \mathrm{C}$ in pork slurries. The pressure treatment at higher than 3000 atm, however, caused some coagulation and discoloration of the pork slurries. On the other hand, yeast was more inactivated at low temperature, especially at sub-zero temperature, than room temperature (Hashizume et al. 1995).

Considering these results, microorganisms may be inactivated at low temperature without any detrimental changes, such as coagulation and discoloration, in raw meat and poultry. Thus, in this study we investigated the effect of the high hydrostatic pressure below $200 \mathrm{MPa}$ at low temperature on the inactivation of Salmonella and Campylobacter species.

\footnotetext{
* Laboratory of Food Process Engineering, Division of Food Biotechnology, Department of Bioscience and Biotechnology, Graduate School of Bioresource and Bioenvironmental Sciences, Kyushu University

+ Corresponding author (E-mail: igura@agr.kyushu-u.ac.jp)
} 


\section{MATERIALS AND METHODS}

\section{Bacterial strains and growth conditions}

Salmonella typhimurium IFO 13245 was grown to late exponential and/or stationary phase in nutrient broth (Eiken Chemical Co., Ltd. Tokyo Japan) at $30^{\circ} \mathrm{C}$ for $18 \mathrm{hr}$. The cells were washed by centrifugation at $1,000 \times g$ and $4{ }^{\circ} \mathrm{C}$ for $15 \mathrm{~min}$ and resuspension with $0.9 \%$ sodium chloride solution for triplicate.

Campylobacter jejuni subsp. jejuni ATCC 33560, Campylobacter jejuni KG1 were grown on Campylobacter blood free selective agar base (CM739, Oxoid Ltd., Hampshire, UK) plates. The incubation was performed under microaerophilic conditions $\left(5 \% \mathrm{O}_{2}, 10 \%\right.$ $\mathrm{CO}_{2}$, and the balance, $\mathrm{N}_{2}$ ) at $42^{\circ} \mathrm{C}$ for 2 days. After the colonies growing on the plates were harvested with $0.9 \%$ sodium chloride solution, the cells were washed by centrifugation at $5,000 \times g$ and $4{ }^{\circ} \mathrm{C}$ for $10 \mathrm{~min}$ and resuspension with $0.9 \%$ sodium chloride solution for triplicate. C. jejuni KG1 was isolated from a patient using Campylobacter blood free selective agar base plates with CCDA selective supplement (SR155, Oxoid) under same condition as above. After isolation the single colony on the plates without CCDA selective supplement was used for confirming as $C$. jejuni by microscopic observation, catalase and hippuric acid tests.

\section{Hydrostatic pressure treatment}

The washed cells of Salmonella and Campylobacter were adjusted to $10^{7}$ colony-forming-unit (CFU) per ml with $0.9 \%$ sodium chloride solution. The cell suspensions $(1.5 \mathrm{ml})$ were sealed into a sterile screw-capped plastic tube (Greiner Labortechnik Co., Ltd., Frickenhausen, Germany). The sample plastic tubes were then pressurized using a prototype pressurization apparatus (Yamamoto Suiatsu Co. Osaka, Japan) to $50-200 \mathrm{MPa}$ at 0,5 , and $10^{\circ} \mathrm{C}$. The come-up time to processing pressure was approximately $10 \mathrm{~min}$ per $50 \mathrm{MPa}$. After holding for $12,30,42$, and $60 \mathrm{~min}$ at each pressure, the samples appropriately diluted and surviving cells were enumerated as below.

The cells of Campylobacter were also tested with poultry thigh purchased from a local supermarket. The raw poultry thighs (ca. $10 \mathrm{~g}$ ) were dipped in the cell suspension of Campylobacter for $10 \mathrm{~min}$ at room temperature, resulting that the cell density was about $10^{6} \mathrm{CFU} / \mathrm{g}$. The raw thigh was vacuum-sealed in polyethylene bag and subjected to high hydrostatic pressure treatment. After pressurization the thigh was placed into a stomacher bag (Oxoid) with $0.9 \%$ sodium chloride solution $(10 \mathrm{ml})$ and homogenized by Stomacher Lab-Blender 400 (Organo Co. Tokyo, Japan) for $2 \mathrm{~min}$, and the surviving cells was enumerated.

\section{Enumeration of viable cells}

After treatments, serial dilutions in $0.9 \%$ sodium chloride solution were performed and surviving cells were enumerated by colony-count method. S. typhimurium was grown on nutrient agar (Eiken Chemical Co., Ltd.) at $30^{\circ} \mathrm{C}$ for $24 \mathrm{~h}$ and C. jejuni was grown on Campylobacter blood free selective agar base plates at $42^{\circ} \mathrm{C}$ for $48 \mathrm{~h}$ under microaerophilic condition. Each measurement was done for triplicate, and arithmetic average was used in figures. Surviving cells were represented as a surviving rate, log $\left(N / N_{0}\right)$, where $N$ is colony counts of the surviving cells and $N_{o}$ is the initial colony counts. 


\section{RESULTS AND DISCUSSION}

Figure 1 shows surviving curves of $S$. typhimurium IFO 13245 after high pressure treatments. The surviving cells decreased linearly with increase of treatment time, except for the treatment of $50 \mathrm{MPa}$ at $0^{\circ} \mathrm{C}, 50$ and $100 \mathrm{MPa}$ at $5{ }^{\circ} \mathrm{C}$, and 50,100 and $125 \mathrm{MPa}$ at $10^{\circ} \mathrm{C}$ at which conditions the cells were hardly inactivated. On the other hand, the cells might be completely inactivated during the come-up time to $200 \mathrm{MPa}$ at each treatment temperature. When using higher treatment pressure, $S$. typhimurium cells were inactivated at higher inactivation rate. The inactivation rate was also higher at $0^{\circ} \mathrm{C}$ compared to 5 and $10^{\circ} \mathrm{C}$. From the surviving curves, the $\mathrm{D}$-values, which is defined as the time required to kill $90 \%$ of microorganisms at certain temperature and pressure, was calculated. When the treatment pressure was $100 \mathrm{MPa}$, the $\mathrm{D}$-values were $20.6,111$, and $250 \mathrm{~min}$ at 0,5 , and $10^{\circ} \mathrm{C}$, respectively. Furthermore, the D-values increased to 5.47 , 15.8 , and $17.6 \mathrm{~min}$ at 0,5 , and $10^{\circ} \mathrm{C}$ after the treatment of $150 \mathrm{MPa}$, respectively.

Vegetative cells are inactivated more easily by the combined use of low temperature and high pressure than by pressurization at room temperature (Sonoike et al. 1992; Hashizume et al. 1995). In our results, S. typhimurium cells were also inactivated effec-
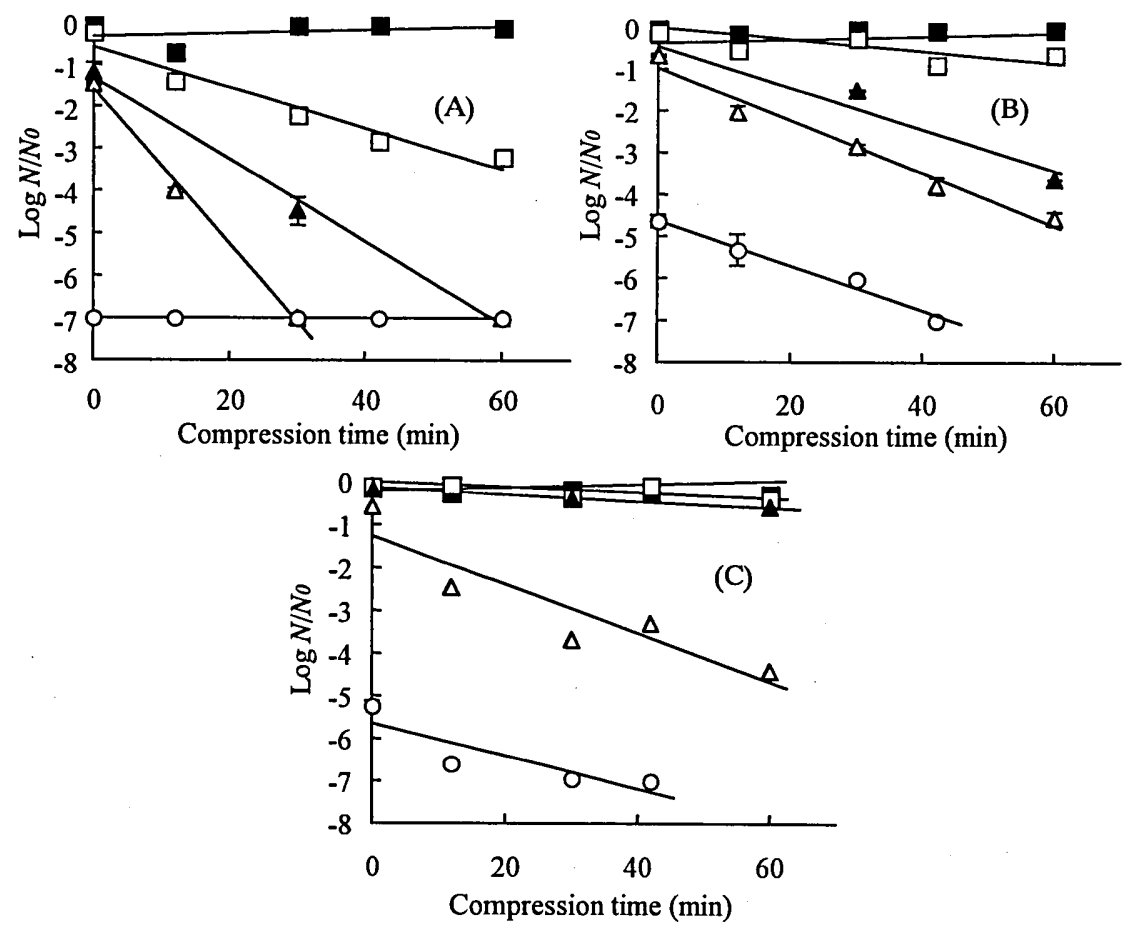

Fig. 1. Surviving curves of $S$. typhimurium after high hydrostatic pressure treatment at various temperatures, (A) $0^{\circ} \mathrm{C}$, (B) $5^{\circ} \mathrm{C}$, and (C) $10^{\circ} \mathrm{C}$. Treatment pressures were (ID) $50,(\square) 100,(\Delta) 125,(\triangle) 150$, and (O) $200 \mathrm{MPa}$. $N$, colony counts of the surviving cells; $N_{0}$, initial colony counts. 
tively at low temperature, and the inactivation rate followed a first-order inactivation. It is considered that the inactivation rate might increased by using lower temperature such as -10 and $-20^{\circ} \mathrm{C}$, according to the study of Hashizume et al. (1995). However, the appearance of raw poultry meat may discolor at these sub-zero temperature, and moreover the processing cost may be more expensive under such these sub-zero temperature. Thus, we selected $0{ }^{\circ} \mathrm{C}$ as a treatment temperature for the following experiments.

Inactivation curves of $C$. jejuni KG1 and ATCC 33560 suspended in $0.9 \%$ sodium chloride solution after high pressure treatments at $0^{\circ} \mathrm{C}$ were shown in Fig. 2. The inactivation rate increased with the increase of treatment pressure, and both Campylobacter species was completely inactivated after first $12 \mathrm{~min}$ holding time at $200 \mathrm{MPa}, 0^{\circ} \mathrm{C} . \mathrm{C}$. jejuni ATCC 33560 showed slightly higher resistance to high hydrostatic pressure compared to C. jejuni KG1. As observed with the high hydrostatic pressure treatment of $S$. typhimurium cell suspension, the inactivation rate of $C$. jejuni cell suspension by the treatment also followed first-order kinetics. The D-values of $C$. jejuni ATCC 33560 were 24.0 and $9.0 \mathrm{~min}$, and those of $C$. jejuni KG1 were 22.9 and $7.1 \mathrm{~min}$ after the treatment at 100 and $150 \mathrm{MPa}$, and $0^{\circ} \mathrm{C}$, respectively.

Each Campylobacter species with chicken thighs was also subjected to high hydrostatic pressure (Fig. 3). The inactivation rates of Campylobacter with thicken thighs decreased at any high hydrostatic pressure used. For instance, a 60-min treatment of $150 \mathrm{MPa}$ at $0^{\circ} \mathrm{C}$ resulted in an approximate 7.0-log cycles reduction of $C$. jejuni ATCC 33560 in $0.9 \%$ sodium chloride solution (Fig. 2), whereas only a 2.5-log cycles reduction with chicken thigh. In fact, certain company reported that the shelf life of poultry meat could be extended from 2 days to 4 days in refrigerator by the high hydrostatic pressure treatment at $200 \mathrm{MPa}$ and $0^{\circ} \mathrm{C}$. Patterson et al. (1995) and Patterson and Kilpatrick (1998) investigated the effect of the high hydrostatic pressure on the inactivation of vegetative bacteria in several substrates, such as buffer, milk, and poultry meat, suggesting that the sensitivities to pressure treatment in different substrates depended on the variety of bacteria. For example, Listeria monocytogenes was more sensitive in
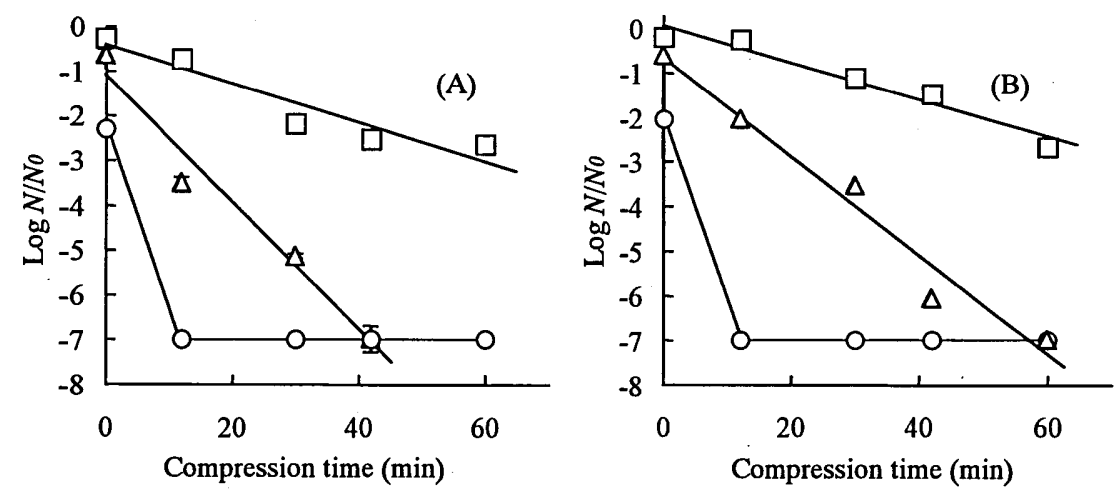

Fig. 2. Surviving curves of (A) C. jejuni KG1 and (B) C. jejuni ATCC 33560 after high hydrostatic pressure treatment in $0.9 \%$ sodium chloride solution at $0{ }^{\circ} \mathrm{C}$. Treatment pressures were $(\square) 100,(\triangle) 150$, and $(\bigcirc) 200 \mathrm{MPa}$. 

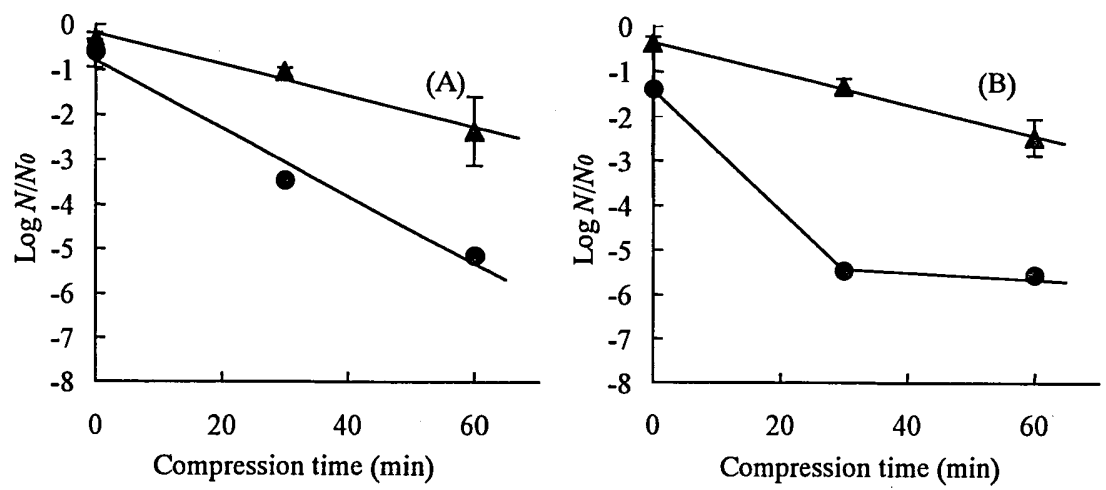

Fig. 3. Surviving curves of (A) C. jejuni KGl and (B) C. jejuni ATCC 33560 after high hydrostatic pressure treatment with poultry thighs at $0{ }^{\circ} \mathrm{C}$. Treatment pressures were (A) 150 and () $200 \mathrm{MPa}$.

poultry meat than phosphate buffer and milk. In contrast, Escherichia coli was more sensitive in phosphate buffer than poultry meat and milk. They also reported that vegetative bacteria in poultry meat were more inactivated at higher treatment temperature than room temperature. However they did not mentioned the appearance of the poultry meat after the high hydrostatic pressure treatment combined with mild heat. The appearance of poultry meat might significantly discolor under such a high treatment temperature.

The high hydrostatic pressure treatment, however, slightly affected the appearance of poultry thighs (illustrate was not shown) under low temperature we used. By the treatment at $200 \mathrm{MPa}, 0^{\circ} \mathrm{C}$ for $60 \mathrm{~min}$, which is a condition enough to kill more than 5 -log cycles of Campylobacter, the surface color of thighs turned whitish, while the inside of thighs was almost same as untreated thighs. Okamoto et al. (1990) studied pressure-induced gels of food proteins, such as an egg, carp actomyosin, and rabbit meat. They reported that gels standing under their own weight maintaining their shapes were obtained at $200 \mathrm{MPa}$ for $30 \mathrm{~min}$ for the carp actomyosin and the rabbit meat paste. From their results, it is considered that the treatment pressure of $200 \mathrm{MPa}$ may be too high to sterilize raw poultry meats without discoloration. To minimize the discoloration, it is required that reduction of treatment time and it may be effective with combination of other procedure, such as an addition of antibiotics (Yuste et al. 1998) and rapid decompression method (Noma et al. 2003).

In conclusion, the use of high hydrostatic pressure under low temperature was effective to inactivate Salmonella and Campylobacter species. Nevertheless the efficiency of inactivation decreased when treated with poultry thighs. In addition, the appearance of poultry thighs slightly discolored due to the denaturation of proteins.

\section{REFERENCES}

Bridgman P. W. 1914 Water, in the liquid and five solid forms, under pressure. Proc. Am. Acad. Art Sci., 45: 441-558 
Cheftel J. C. 1995 Review: High-pressure, microbial inactivation and food preservation. Food Sci. Technol. Int., 1: 75-90

Hashizume C., K. Kimura and R. Hayashi 1995 Kinetic analysis of yeast inactivation by high pressure treatment under low temperature. Biosci. Biotechnol. Biochem., 59: 1455-1458

Hayakawa I., J. Kajihara, K. Morikawa, M. Oda and Y. Fujio 1992 Denaturation of bovine serum-albumin (BSA) and ovalbumin by high pressure, heat and chemicals. J. Food Sci., 57(2): 288-292

Hayakawa I., T. Kanno, M. Tomita and Y. Fujio 1994 Application of high-pressure for spore inactivation and protein denaturation. J. Food Sci., 59(1): 159-163

Hayakawa I, Y. Y. Linko and P. Linko 1996 Mechanism of high pressure denaturation of proteins. Lebensm. - Wiss. Technol., 29(8): 756-762

Noma S, M. Shimoda and I. Hayakawa 2002 Inactivation of vegetative bacteria by rapid decompression treatment. J. Food Sci., 67(9): 3408-3411

Okamoto M., Y. Kawamura and R. Hayashi 1990 Application of high pressure to food processing: Textural comparison of pressure-and heat-induced gels of food proteins. Agric. Biol. Chem., 54(1): 183-189

Sale A. J. H., G. W. Gould and W. A. Hamilton 1970 Inactivation of bacterial spores by hydrostatic pressure. J. Gen. Microbiol., 60: 323-334

Shigehisa T., T. Ohmori, A. Saito, S. Taji and R. Hayashi 1991 Effects of high hydrostatic pressure on characteristics of pork slurries and inactivation of microorganisms associated with meat and meat products. Int. J. Food Microbiol., 12: 207-216

Sonoike K., T. Setoyama, Y. Kuma and S. Kobayashi 1992 Effect of pressure and temperature on the death rates of Lactobacillus casei and Escherichia coli. In "High pressure and biotechnology", Vol. 224, ed. by C. Balny, R. Hayashi, K. Heremans and P. Masson, Colloques INSERM, Libbey Eurotext, Montrouge, pp. 297-301

Yuste J., M. Mor-Mur, M. Capellas, B. Guamis and R. Pla 1998 Microbiological quality of mechanically recovered poultry meat treated with high hydrostatic pressure and nisin. Food Microbiol., 15: $407-414$

Yuste J., M. Capellas, R. Pla, D. Y. C. Fung and M. Mor-Mur 2001 High pressure processing for food safety and preservation: A review. J. Rapid Methods Autom. Microbiol., 9: 1-10 